\title{
CHRISTMAS IN THE TRADITIONS OF RUSSIAN MINING SETTLEMENTS OF THE KOMI REPUBLIC (AS PER RECORDS OF THE EARLY TWENTY-FIRST CENTURY)
}

\section{Yulia Krasheninnikova}

Senior Research Fellow

Department of Folklore, Institute of Language, Literature, and History

Komi Science Centre, Russian Academy of Sciences, Russia

Email:krasheninnikova@rambler.ru

\section{Svetlana Nizovtseva}

Research Fellow

Department of Folklore, Institute of Language, Literature, and History

Komi Science Centre, Russian Academy of Sciences, Russia

Email: svetlananiz@mail.ru

\begin{abstract}
The article introduces folklore materials collected in the early twentyfirst century mostly from the Russian population of the mining settlements in the Komi Republic, which were founded when iron mining started in the area in the middle of the eighteenth century. The authors analyse the Christmas rituals and poetry used by children and adults when visiting neighbours at Christmas. The use of certain scenarios related to the celebration of Christmas and the Christmas period shows how the local traditions that developed among the varied population were integrated into the culture of Russian North and Central Russia.
\end{abstract}

Keywords: calendar complex, Christmas ritual, Christmas visitation, Komi Republic, praise, Russian folklore traditions

\section{CHRISTMAS CEREMONIALISM OF THE RUSSIAN LOCAL MINING TRADITIONS}

From 2008 to 2015, we collected texts about the celebration of Christmas and Christmas rituals from the population of three mining settlements. The texts help to understand the traditions of the first third to half of the twentieth century. We have analysed the collection of various sizes and informational capacities containing very specific information about the contents of the ritual 
activities; popular definitions, clarifying details of genres, peculiarities of performance, and contents of the ritual texts; gender, age, temporal, and territorial markers; explanation of the reasons for and consequences of performing a certain action or text from the point of view of the tradition-bearers.

House visitations to celebrate Christmas, dressing up, and divinations are the typical attributes of local traditional Christmas rituals. Correspondingly, we have divided the stories of Christmas rituals into three theme blocks. First, the stories of celebration - ritual house visitations by children and adults. The second theme, addressed by almost each and every interviewee, is dressing up. These texts cover costumed people's behaviour outside and inside the home, period of activity, costumes (list of elements and quality characteristics), masks, dressing-up characters, offering food to people wearing costumes. Less popular are topics related to making masks and psychological experiences of meeting the guisers or having been a Christmas guiser.

Lastly, we included many texts and listed witnesses concerning foretelling rituals - divinations for the name or appearance of a future husband or for the fortune (marriage, death, pregnancy, etc.) by using fence poles, flat cakes, footwear, the shadow of burnt paper, water frozen in the spoon, wedding rings, animals, etc., by listening at the cross-roads or at the window of the house, as well as narrations on the divinations which were fulfilled or did not come true, and actual stories of the interviewees' lives.

Although the materials are fragmented and varied, it is possible to find stable and optional elements in each theme block, showing the stability/optionality, regularity/irregularity, popularity/unpopularity, reproducibility/uniqueness of a verbal text, object, attribute, etc. in the tradition. Due to the vast amount of materials and the limited space of the article, we will cover in detail texts describing the visiting of homes during Christmas. Materials on Christmas celebrations in the Russian mining villages of the republic are fragmented and do not allow reconstructing a comprehensive picture of this phenomenon. At the same time, using research summarising the rituals in the Russian population of other regions and local traditions makes it possible to restore some aspects of Christ worship and provides some general and specific details of local rituals. 


\section{DETAILS OF CEREMONIAL ETIQUETTE}

We have collected materials about the secular praise of Christ, i.e., home visitation by the secular population. We did not collect any information about church or church-related visitations by priests, clergy, students of church schools, church choir, beggars (classification by Alexander Rozov; see Rozov 1999: 25). According to the interviewees, the Christ-worship visitations of homes by adults and children used to begin early in the morning on 7 January, i.e., on Christmas Day': 'When we were young, we used to go out to worship... It was still dark outside, but we ran to worship in the morning. ... Here we were, early in the morning on Christmas Day...'2

There is little or no evidence to any preparation, composition, gender, or age of the worship groups. The records mention both group and individual worship visitations, for example: 'It is Christmas worship, yes, Christmas. That I know, they came to me, I lived in this house already, they came to me. Kostikha, like, Kosarikha ${ }^{3}$, and... six people'. ${ }^{4}$ Judging by the number of records of the poetical texts and comments from the interviewees, the children's Christmas visitations were popular in all three mining villages, especially in Kazhym and Nyuchpas, but in the village of Nyuvchim the data about Christmas celebrations and 'singing divine songs' present sporadic, solitary examples. It is known that children more often went to worship at their relatives: 'We did not go much to strangers; we went to our relatives. Where the relatives are, there they run...'5; 'I also went to my grandmother and to my aunties, I went. ... I went to mine'6, etc.

There is no information about the use in Kazhym, Nyuchpas, or Nyuvchim of any special worship attributes (star, lantern, crèche, 'racheya', etc.) that were popular in the Northern Russian traditions.

At the entrance of the house, the worshippers got the host's permission to perform the worship ritual. The permission was granted in the form of implicit dialogue, always in the same form: 'Do you praise Christ?' - 'Praise!' Then the ritual started, followed by prayers and/or Christmas rhymes.

The hosts would greet the worshippers and give them pastry, eggs, candies, and small change, which the children would share:

Somebody would give us two roubles; if someone was baking cakes, then they would give us; we would come with a bag. And we were happy, as those were hungry times...8

They would give us a kopek, perhaps, or something similar, a candy, a cookie, or something baked...9 


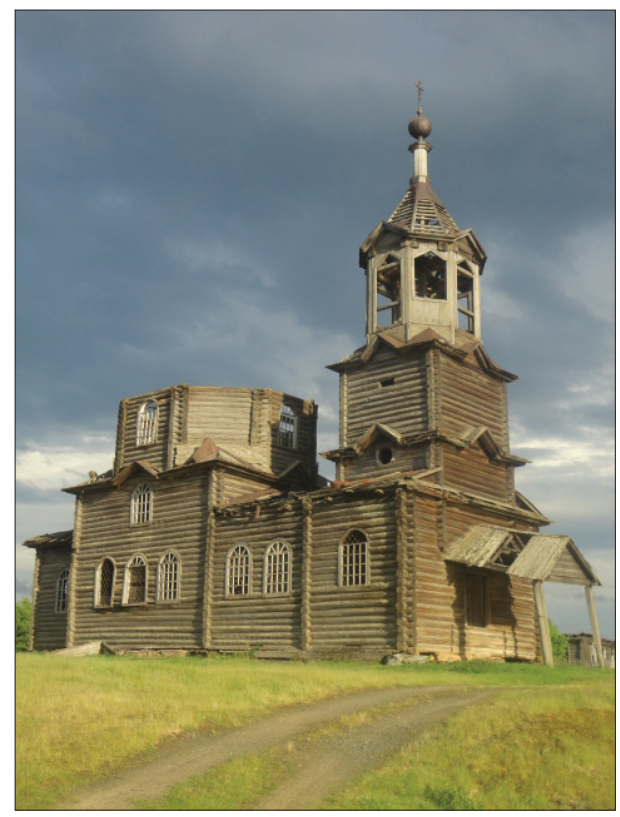

Figure 1. The Church of St. Prokopy of Ustyug in Nyuchpas, Koygorodsky District. Photograph by Yulia Krasheninnikova 2013.

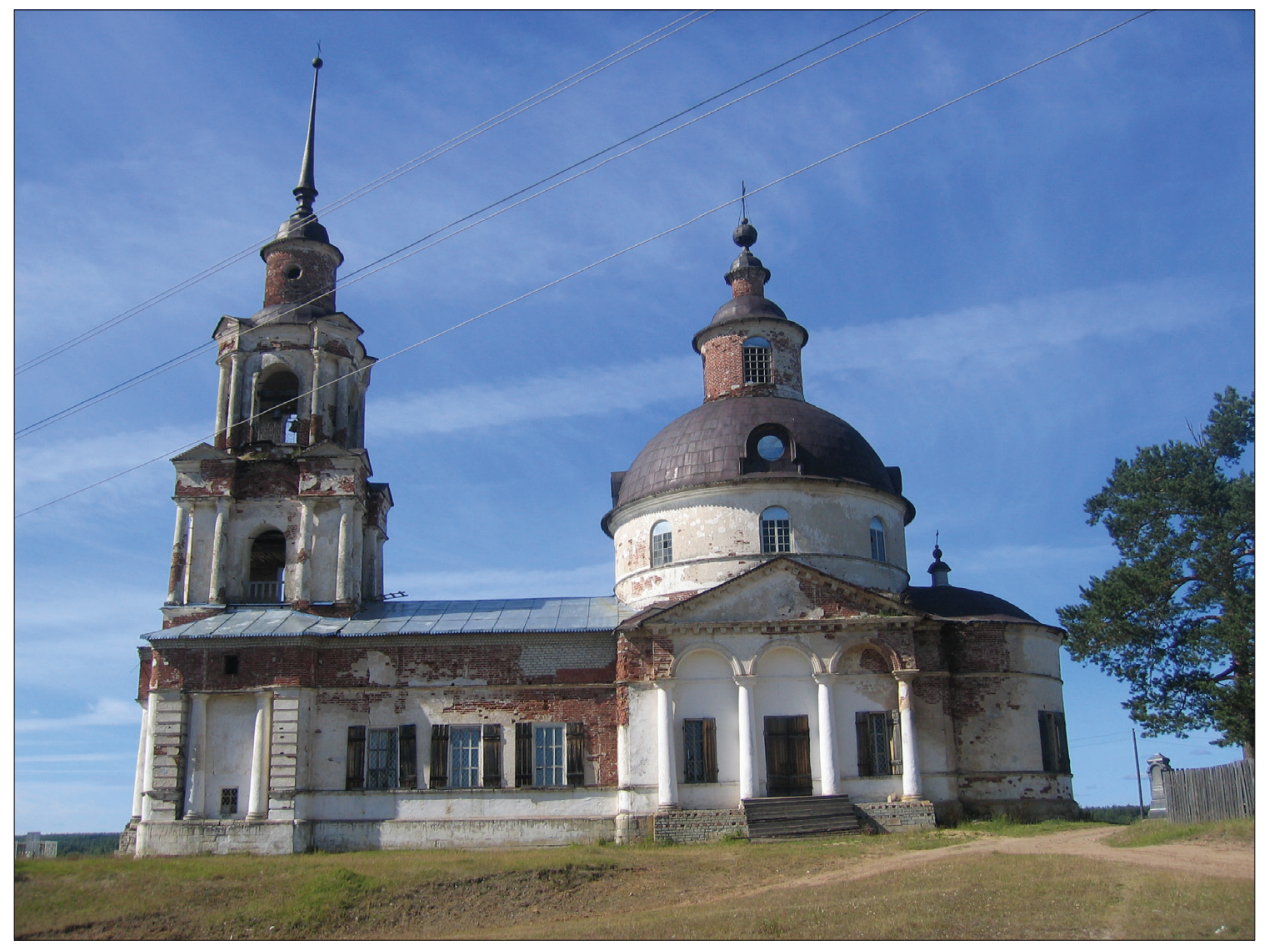

Figure 2. The Church of St. Dimitry of Rostov in Kazhym, Koygorodsky District. Photograph by Yulia Krasheninnikova 2010. 
Well, someone would give a cake, someone would give a bun, someone would give something else. But they seldom gave money. But they did. Someone would give small change, kopeks. And once we went with one woman, well, a girl, and they gave us five roubles. We were almost mad, we ran desperately to the shop to change the five roubles... ${ }^{10}$

It was generally assumed that paying to the worshippers would bring luck to the family, so the hosts tried to satisfy their request. Research shows that monetary gifts are directly tied to the veneration of ancestors and have a prognostic, producing, and protective function: 'The desire to pay the visitors well to ensure the wellness of the household and the family was supported by a rather archaic belief that the deceased ancestors can not only tell the future but also influence life in other ways' (Vinogradova 1982: 148).

Interviewees born in the 1940s spoke about the declining tradition of Christmas visitations. According to them, the tradition began fading away approximately at the end of the 1950s:

Юньчик, юньчик, прыг на стульчик, стульчик на бочок, дай пятачок [Little boy, little boy, jumps on a chair, the chair trips, give me a fiver.] It was [performed] by little children. And the adults ... would sing something like in the church, that was what they sang. They also took part in the visits, well, when I was young. And later, they stopped the worship, and children stopped visiting, but before, we used to go often. ${ }^{11}$

\section{THE LOCAL CHRISTMAS REPERTOIRE IN THE CONTEXT OF THE ALL-RUSSIAN TRADITION}

The repertoire of adult worshippers included the troparion 'Your Christmas Christ our Lord...' and the hirmos 'Christ is being born, praise...' Sometimes, these were also sung by children and teenagers, who had learned it from their parents. When interviewed, the interviewees tried to follow the traditional way of singing (singing and reciting), combining the fragments of various liturgical texts into one text or borrowing and combining fragments from various canonical texts, affording alterations of canonical texts in their oral manifestation (срящите - здравствуйте 'meet him - greet him', лирови свет разула лира и всех разула 'world with the light of knowledge - peace and reason to all', etc.; bold font shows the similarities of the texts): 
[Praiser's repertoire]

Here he starts praising:

Христос рождается славитЕ!

Христос в небе здравствуйте!

Христос на зеллевозноситеся!

Воспойте, люди, яко

прославился!

Christ is being born - praise him! Christ is in the sky - greet him! Christ is on the Earth - ascend! Sing people, as we are glorious!

Рождество Твое Христе

Боже нас,

Воссияя лира и всех разула.

Тебе кланяелся, света

божьего...

Christ, us Lord, Your Birth

Shining peace and reason to all.

We bow to you, divine light...

[Further] I forgot... ${ }^{12}$
[Canonical texts]

Canon 1. Hirmos

Христос рождается славите!

Христос с Небес-срящите.

Христос на зеллевозноситеся.

Пойте Господеви, вся зелля, И веселием воспойте,

людие,

Яко прославися...

Christ is being born - praise him! Christ from the sky - meet him! Christ is on the Earth - ascend. Sing the God, the whole earth And sing with joy, people

As $\mathrm{He}$ is glorious...

Troparion, mode 4

Рождество Твое Христе

Боже наш,

Возсия мирови свет разула, В нел бо звездал служашии

Звездою учахуся

Тебе кланятися, Солниу

Правды,

И Тебе ведети с высоты

востока.

Господи, слава Тебе.

Christ, our Lord, Your Birth

Enlightened the world with the light of knowledge

Because through Him those who served the stars

We taught by the star

To bow to you, Sun of the Truth And know you, the sun rising to the high.

Lord, Glory to You. (Azbuka) ${ }^{13}$ 
The reasons for the fragmentation of the texts, the inconsistencies in the descriptions of the Christmas visitation process, and the lack of earlier evidence can be attributed in part to the age of the interviewee answering the questions (most of them were born in the 1930s), the fact that churches were closed in mining villages in that period, and that the Christmas rituals were disapproved. All of this prevents studying the phenomenon in more detail.

The texts and recollections about Christmas celebrations as presented by the interviewees who were children at the time, based on their personal experience and personal feelings, are collected more often. These records, in addition to the description of worship actions, include the time and age markers, motivation, examples of popular terminology, and various versions of poetical texts.

In these mining settlement traditions, children performed the Christmas rhymes унчик, the versions of which were recorded in many Russian traditions, in particular in Arkhangelsk, Vologda, Vyatka, Ulyanovsk, Nizhniy Novgorod, and Voronezh oblasts, Prikamye (Vlasov 1995: 156; Drannikova 2000: 46; Chernykh 2008: 101; Korepova 2009: 40; Voroshilin 2009: 31; Safronov 2011), etc. Alexander Rozov, referring to Yevgeny Kostiukhin, notes that this tradition originated from Polish schoolchildren; then, it was borrowed by Ukrainians and Belarusians, and was later adopted in Russia (Rozov 1999: 48). The researchers do not agree about the genre of the texts: in scientific terminology, they are referred to as 'glorifying rhymes' (Korepova 2009: 39-40), 'Christmas song', which were 'chanted or sang' (Rozov 1999: 48), Christmas carol (Vlasov 1995: 156), рацейка (Drannikova 2000: 46) ${ }^{14}$, славка 'glorifying chant' (Chernykh 2008: 97, 101), etc. Publishers and collectors in the nineteenth century called these texts children's ratseya (P.A. Bessonov, G.K. Zavoiko, A. Sheshenin), припевка 'ditty', присказка 'saying' (G.S. Vinogradov, A.N. Sobolev) (Rozov 1999: 48).

Local popular terminology offers terms like присказулька 'short tale', припевка 'ditty', стишок 'short poem'. ${ }^{15}$ Commenting the peculiarities of performing these texts, the interviewees say that they are sang and spoken aloud or refer to the singing-recitative manner: 'Words, words they say as the song goes. They sing it a bit, just like a song. ${ }^{16}$ By these definitions, the interviewees refer to the brevity and laconism of the form, often light, casual, funny content, and peculiarities of performance; and refer to the ideas developed within the tradition of the children's genre as non-serious, in a simple form, and not meaningful. ${ }^{17}$

Modern examples show degrees of textual variability: from 2 to 4 lines to longer versions, where at the beginning, a character of a boy (вьюньчик /юньчик) is introduced, then the main part describes his actions ('sat on a chair', 'jumped/ jumps on the chair', 'plays reedpipe', 'gathers guests', 'congratulates Christ', 'glorifies Christ'), and the conclusion includes a request for a gift ('give me a rouble/fiver', 'open your chest, give me a fiver', etc.) and something tasty ('to the children for ginger bread'): 
Маленький юньчик,

Сел на стульчик,

Дудочкой играет,

Христа поздравляет.

Со скотол, животол,

С пшеницею, с овсол.

Тьь, хозяин-лужичок,

Полезай в сундучок,

Доставай пятачок.

Нал на орешки,

Деткал на потешки.
Little iun'chik [little boy],

Sits on a chair,

Plays the reedpipe,

\section{Congratulates Christ.}

With cattle, with belly,

With wheat, with oats.

You, the host man,

Go to your chest,

Get a fiver.

For us to buy nuts,

For the children to have fun. ${ }^{18}$

Shorter versions have been recorded, where the idea of glorifying the birth of Christ or Christ and those present was the central motif:

Юньчик, юньчик,

Сел на стульчик

В трубочку играет

Христа поздравляет.
Iun'chik, iun'chik [little boy, little boy], Sits on a chair, Plays the pipe

Congratulates Christ. ${ }^{19}$

Or:

Вьюньчик, вьюньчик,

Сел на стульчик.

Дедушку и бабушку,

И Христа поздравляет.
Viun'chik, v’iun'chik [Littleboy, littleboy], Sits on a chair,

Grandfather and grandmother and Christ he congratulates. ${ }^{20}$

Some poetical versions show the 'loss of the main part of Christmas rituals glorification of Christ' (Rozov 1999: 48) and present the idea of request for money or something tasty:

Юньчик, юньчик,

Скок на стульчик.

Стульчик на бочок,

Дайте пятачок.

Or:

Маленький юньчик,

Прыгнул на стульчик.

Я пришел не так -

Дайте денюжку пятак!
Iun'chik, iun'chik [little boy, little boy], Jumped on a chair, The chair tripped

Give me a fiver. ${ }^{21}$
Little iun'chik [little boy], Jumped on a chair, I have come not for nothing Give me some money, a fiver! ${ }^{22}$ 
A. Rozov notes that some versions of the text were collected in the 1970s1990s 'both from elderly singers recollecting their childhood, and from boys and girls, and highlights that the main goal of these poems was 'to make fun, entertain the audience', whereas performing 'unchik' by children and adults in the 1920s-1940s 'definitely illustrates the decline of the Christ glorification tradition' (Rozov 1999: 48). Data from the first decade of the twenty-first century supports these conclusions. Persons who witnessed performing $у н ц и к$ in the 1930s-1940s and the motivations of interviewees suggest that the aesthetical function of the texts was less important than the practical function (receiving food or things), as explained by the interviewees, or rather, by the difficult situation of the local people:

... and they would compliment you, give something to you, a candy if they have. Maybe only some sugar, as there was nothing tasty to give. Or a cake, perhaps... ${ }^{23}$

Whatever they had, who gave candies, who gave cookies, who would give some money, some kopeks, they gave whatever they could. ${ }^{24}$

So, some would give money - kopeks, some would give a pastry, some would give candies... And we would perform, and then will buy with this money a jacket, some fabric for a jacket, a skirt, or a dress; we had nothing, we lived poor. ${ }^{25}$

Secondly, the interviewees clearly distinguish 'worship' genres from adult and children's repertoire. Individual witnesses said that children could also 'praise with prayer'. This type of worship was possible if adults had taught children to pray, and therefore, the main criteria for the performance were whether you were taught or not taught, whether you can or cannot pray. However, the comments consistently illustrate that prayers are performed by the adults, while унчик is for children:

They, little ones, sang it [унчик - Y.K., S.N.], while the adults - they would sing 'Christ is being born - praise him!'26

- They say that people in old times would visit and praise Christmas?

- Those who knew, old people....

- Did children praise, too?

- Children - no, they only listened.

- Did they not sing 'Little iunchik?

-Oh, iun'chik, yes, they sang, sang... ${ }^{27}$

...children said [унчик - Y.K., S.N.]. And the adults had a proper prayer. ${ }^{28}$ 
Commenting the age distribution of 'worship' genres, the interviewees implicitly highlighted the 'value' of ritual texts, their importance, and significance for the ritual: adults had a 'proper prayer'29, while children spoke 'simple words'.

Thirdly, the interviewees attempt to separate the local (old-timer) and 'imported' (in particular, by the new settlers and seasonal workers) repertoires, paying attention to the time markers and place of origin of a text. An interviewee, commenting on one of the унчик examples, marks terminological differences in describing the Christmas home visitation process: славить Рождество (glorify Christmas) (variant: ходить славить (go to glorify) - is a local term, while колядовать (sing carols) is a Ukrainian tradition term:

- ...went to the neighbours and koliadovali the Ukrainian way.

- Did you call it so?

- No. It is in Ukrainian 'koliadovali'.

- And how did you call it?

- Worship... ${ }^{30}$

In another example from the same village, an interviewee explains singing koliada ${ }^{31}$ :

- Koliada is there, in the south [territories], we did not sing koliada.

- Where is 'there'?

- For example, I lived in Belarus, so there they went koliadovat'. But here they did not koliadovali, they slavili. And there were koliadki. ${ }^{32}$

Some comments characterise the contents of local children's Christmas songs. The interviewee quotes a part of a children's decrying song sung at Christmas, which was performed in the event of poor wages, and says that it was sung in Belarus, while in Kazhym, children sing 'all kinds of Christmas songs'. By this implicit opposition (smutty vs. decent, appropriate), the content of local children's songs is characterised as positive or neutral:

- Our children would sing this smutty song:

'And in this hut

Nothing to give,

The furnace is shabby,

The housewife [name] is dirty, messy'.

Then, they would run out with sticks and chase away.

- Did they sing this in your neighbourhood in Belarus?

- Yes, this was sung there. And here, children sing all kinds of Christmas songs... ${ }^{33}$

The evidence proves that the tradition of коляда (Christmas visitations with carols) might have existed in the mining villages. The interviewees mention 
коляда as part of the local tradition, using the term коляда and defining the actions of worshippers with the verb колядовать. For example, the following is a fragment of an interview with an interviewee from Kirov Oblast, who moved to the village of Kazhym in 1955:

- And during Christmas, there are koliadki, yes there are.

- Is it what you called it here, koliadki?

- For example, in my house, the grannies, yes, would come, and I lived with my mother-in-law, and say: 'May we koliadovat'?'

- Was it in Kirov Oblast?

- No, it was here, [when] I lived with my mother-in-law. They came to koliadovat'. Sang: 'Коляда mьı, коляда, // Tьь да выйди за ворота... [Koliada, you koliada, // You get out of the gate...' Then something like '...Не дашь пирожка, // Mь, говорит, теленка за рога... [...If you do not give us cake, // We, say, take your calf by the horns...] And then would start something, some пискатульки ${ }^{34}$. Yeah, well, then we give them something. Children would also come... ${ }^{35}$

The interviewee cites two fragments of the коляда, where the first fragment is also part of the worship visitation and depicts the coming of worshippers (i.e., it is the introductory part). The second fragment is a threatening request for alms or food. Vladimir Chicherov analyses in detail this type of New Year wish songs, which include a request for ritual alms. He notes that the songs of this type are seldom individual but 'are almost always parts from another text' (Chicherov 1957: 124). In the songs, the request for alms 'is in the form of a threat to cause damage to the house unless the request is satisfied' (ibid.), 'it is a demand that becomes a threat to bring trouble' (Chicherov 1957: 126). ${ }^{36}$

In another fragment of a коляда collected in the Nyuchpas village, we see an allusion to the Яблочко (Apple) song that was popular in the city environment: ${ }^{37}$

- They would come with koliada. They would bring something, somewhat... 'Коляда ты, коляда, куда катишься? // Ко лне в рот попадешь, не воротишься...' [Koliada you, koliada, where are you rolling? // You will get into my mouth and will not come back...] That was what they sang. They would come with koliada, I lived in this house already....

- Did they come with koliada here?

- Yes, yes.

- So they would celebrate Christmas on the seventh of January?

- Yes.

- Do they sing a Christmas prayer? 
- Yes. [The next day] koliada: 'Коляда, ты коляда, куда катишься? // Ко мне в рот ведь попадешь, не воротишься...' [Koliada you, koliada, where are you rolling? // You will get into my mouth and will not come back...] That was what they said. They would come with this. Well, they sing some prayers, not what I tell you.

- Did they come with koliada on the second day?

- Yes, on the second day, they would come with koliada. [And on the third day] girls would dress-up and come. ${ }^{38}$

\section{CONCLUSION}

Though the data are fragmented and mosaic, we can say that the Christmas ritual as part of the popular calendar of the Russian population in the Komi Republic mining villages was rather dense, and similar to the other Russian local traditions in respect of symbolic actions, modes of behaviour, types of magic practices, and samples of verbal folklore. The use of certain scenarios, related to Christmas celebrations and the Christmas period, shows how the local traditions, formed by the ethnically varied population (see Krasheninnikova 2019), 'build in' the culture of the Russian North and Central Russia, and some relics of the mother cultures have become integral parts of the local traditions in the course of development of the latter. The analysis of the Christmas rituals and poetry in the records of the early twenty-first century shows similarities of the contents of the ritual activities (house visitations in order to glorify Christmas), modes of behaviour, types of magic practices (dressing-up), and verbal folklore with other local Russian traditions. The modern records also show the decline of the glorifying Christmas tradition, which is manifested in the lack of clear information about the age, gender, and number of worshippers, absence of the praising attributes (star, lantern, crèche, etc.), visitations mostly of the relatives by children, and reduction of the poetic repertoire.

\section{NOTES}

1 The Catholic Church and the Protestant streams of Christianity celebrate Christmas Day on 25 December according to the modern Gregorian calendar. The Orthodox Church celebrates Christmas Day on 25 December according to the Julian calendar (or 'old style'), which corresponds to 7 January of the modern Gregorian calendar (see https://ria.ru/20071224/93923436.html, last accessed on 23 July 2019).

${ }^{2}$ Recorded by Y. Krasheninnikova in Nyuchpas, on 19.06.2013, from P.N. Kozlova, born in 1942.

${ }^{3}$ Local female nicknames; the wives were called by the family names of their husbands; therefore, Kosarikha's husband was Kosarev, and Kostikha's husband - probably Kostin. 
4 Recorded by Y. Krasheninnikova in Nyuchpas, on 18.06.2013, from N.N. Chesnokova, born in 1933, and G.N. Mikhailova, born in 1928.

5 Recorded by Y. Krasheninnikova in Nyuchpas, on 18.06.2013, from L.N. Kushkhova, born in 1931, O.N. Obrezanova, born in 1937, and E.N. Karmanova, born in 1944.

${ }^{6}$ Recorded by Y. Krasheninnikova in Kazhym on 2.07.2010, from L.V.Vavilova, born in 1930.

7 Aleksandr Rozov, with reference to data by S. Dmitrieva (Dmitrieva 1988: 19), mentions рачея 'a rack decorated with multicolored pieces of paper' as a local attribute of Christmas Glorification of Christ in Mezensky and Kholmogorsky districts of Arkhangelsk Province (Rozov 1999: 40).

8 Recorded by S. Nizovtseva and P. Shakhmatskaya in Kazhym, on 24.06.2013, from N.V. Guryeva, born in 1938.

9 Recorded by S. Nizovtseva and P. Shakhmatskaya in Nyuchpas, on 18.06.2013, from E.N. Kosareva, born in 1948.

${ }^{10}$ Recorded by Y. Krasheninnikova in Kazhym, on 25.06.2013, from I.N. Kuzmina, born in 1927, and N.K. Zadorozhnaya, born in 1955.

${ }^{11}$ Recorded by S. Nizovtseva and P. Shakhmatskaya in Nyuchpas, on 19.06.2013, from M.N. Volodicheva, born in 1948.

12 Recorded by L. Lobanova, S. Nizovtseva, and A. Rassykhaev in Nyuchpas, on 5.06.2011, from D.I. Kostin, born in 1935.

${ }^{13}$ A. Rozov says that in the nineteenth century, in the course of glorification by the clergy, they performed two pieces of the big Christmas repertoire that they usually perform in the church - the troparion 'Your Birth, Christ our God', and the kondak 'Today Virgin Gives Birth to Ever-Existing' (Rozov 1999: 27), as well as secular praisers - the troparion 'Your Birth, Christ out God', the kondak 'Today Virgin', the hirmos 'Christ is Being Born', and stichera, adding congratulations to the host on the holiday or wishes of long life (Rozov 1999: 41).

${ }^{14}$ See also G. Vinogradov's term 'ratseika transformed into counting rhyme' (Vinogradov 1998: 356, No. 406 a, b, v).

15 The meanings of these words include the following: присказулька - diminutive from the noun присказка 'short funny story, a joke' (Ushakov 1939: vol. 3, col. 848); присказка - fig. col. 'storyteller's introduction' (Efremova 2000); Vologda, Perm 'joke, saying'; Vyatka 'ditty' (SRNG 1997: 383); припевка - Vyatka, South-Siberian 'ditty'; Vologda, Perm. In the wedding ritual a praising short song, often remunerated with gifts, money, etc. (SRNG 1997: 338).

${ }^{16}$ Recorded by Y. Krasheninnikova in Kazhym, on 3.07.2010, from T.S. Filyova, born in 1934, origin. from Brest Oblast, Belarus.

${ }^{17}$ About the use of popular terminology to describe the genre and its characteristics, see Krasheninnikova 2011.

${ }^{18}$ Recorded by Y. Krasheninnikova in Kazhym, on 3.07.2010, from V.N. Filyov, born in 1934, and T.S. Filyova, born in 1934, origin. from Brest Oblast, Belarus.

${ }^{19}$ Recorded by Y. Krasheninnikova in Kazhym, on 24.06.2013, from D.N. Shishnev, born in 1932. 
${ }^{20}$ Recorded by Y. Krasheninnikova and S. Nizovtseva in Kazhym, on 26.06.2013, from G.A. Karavaeva, born in 1939.

${ }^{21}$ Recorded by Y. Krasheninnikova in Nyuchpas, on 19.06.2013, from P.N. Kozlova, born in 1942, origin. from Nyuchpas village.

${ }^{22}$ Recorded by A. Rassykhaev, L. Lobanova, and S. Nizovtseva in Nyuchpas, on 5.06.2011, from D.I. Kostin, born in 1935, and A.N. Kostina, born in 1934, origin. from Vygonichskiy Region of Bryansk Oblast; moved to Nyuchpas in 1958.

${ }^{23}$ Recorded by Y. Krasheninnikova in Kazhym, on 2.07.2010, from L.V. Vavilova, born in 1930.

${ }^{24}$ Recorded by Y. Krasheninnikova in Kazhym, on 3.07.2010, from V.N. Filyov, born in 1934, and T.S. Filyova, born in 1934, origin. from Brest Oblast, Belarus.

${ }^{25}$ Recorded by Y. Krasheninnikova in Nyuchpas, on 19.06.2013, from P.N. Kozlova, born in 1942.

${ }^{26}$ Recorded by Y. Krasheninnikova in Kazhym, on 25.06.2013, from I.N. Kuzmina, born in 1927.

${ }^{27}$ Recorded by Y. Krasheninnikova in Kazhym, on 25.06.2013, from V.D. Makarova, born in 1925 .

${ }^{28}$ Recorded by Y. Krasheninnikova and S. Nizovtseva in Kazhym, on 26.06.2013, from V.A. Karavaeva, born in 1939.

${ }^{29}$ In this respect, the local popular definition of the word молитва 'prayer' coincides with the connotations that it has in the culture. Most dictionaries are unanimous about the meaning of the word лолитва - 'canonical verbal text that believers pronounce when addressing the god' (Ushakov 1938: 247; see also Ozhegov 1987 [1949]: 307-308); 'praising, thankful or pleading address to God or saints; prescribed text, to be read or pronounced by a believer when addressing God or saints' (Efremova 2000); 'plead, petition; ... word, addressed to God' (SRIa 1982: 243-244).

${ }^{30}$ Recorded by S. Nizovtseva and P. Shakhmatskaya in Kazhym, on 22.06.2013, from I.M. Dobrova, born in 1934.

${ }^{31}$ We would like to also mention that this genre was popular in the Russian North, in particular in Vologda and Arkhangelsk provinces, and the texts of koliadka were performed both by adults and children (Rozov 1999: 42, 51).

${ }^{32}$ Recorded by Y. Krasheninnikova and S. Nizovtseva in Kazhym, on 26.06.2013, from G.A. Karavaeva, born in 1939.

${ }^{33}$ Recorded by Y. Krasheninnikova in Kazhym, on 3.07.2010, from T.S. Filyova, born in 1934, origin. from Brest Oblast, Belarus.

${ }^{34}$ According to the audio record; it should be read as присказульки.

${ }^{35}$ Recorded by Y. Krasheninnikova, S. Nizovtseva, and P. Shakhmatskaya in Kazhym, on 23.06.2013, from A.A. Burylova, born in 1933, origin. from Bol'shoi Kashnur village in Sovetskiy Region, Kirov Oblast.

${ }^{36}$ See Chicherov 1957: 123-130 about these texts and peculiarities of contaminations. 
${ }^{37} \mathrm{~S}$. Neklyudov in his analysis of the genres of contemporary city folklore mentions Яблочко (Apple) - a song of the late 1940s: 'Яблочко ( Эх, яблочко), куда ( куды) котишься? (sic!) / Ко мне в рот попадешь - не воротишься!' [Apple, where are you rolling? / You will get into my mouth and won't come back!]' The text ... was never perceived as unfinished and did not need any continuation' (Neklyudov 2011: 20). S. Neklyudov does not exclude that 'You will get into my mouth' is a reframing of the original 'You will get to Rostov' and explains that 'from a child's point of view it is much more natural for an apple to get into somebody's mouth than to an unknown Rostov' (Neklyudov 2011: 22).

${ }^{38}$ Recorded by Y. Krasheninnikova in Nyuchpas, on 18.06.2013, from N.N. Chesnokova, born in 1933, and G.N. Mikhailova, born in 1928.

\section{REFERENCES}

Azbuka = Pravoslavnoe bogosluzhenie. [Russian Orthodox Liturgy.] Available at https:// azbyka.ru/bogosluzhenie/kanonnik/kanon04.shtml, last accessed on 27 June 2019.

Chernykh, Aleksandr 2008. Rozhdestvenskie i novogodnie obkhody v russkikh traditsiiakh Permskogo Prikam'ia v kontse XIX - pervoi polovine XX veka. [Christmas and New Year Visitations in the Russian Traditions of Perm Kama Region in the Late 19th - First Half of the 20th Centuries.] Vestnik Udmurtskogo Universiteta. Seriia Istoriia i filologiia. [Bulletin of Udmurt University. Series of History and Philology.] No. 1, pp. 89-108. Available at http://ru.history.vestnik.udsu.ru/files/ originsl_articles/vuu_08_051_10.pdf, last accessed on 27 June 2019.

Chicherov, Vladimir 1957. Zimnii period russkogo narodnogo zemledel'cheskogo kalendaria XVI-XIX vekov: ocherki po istorii narodnykh verovanii. [Winter Period of the Russian Agricultural Calendar in the 16th-19th Centuries: Essays on the History of Folk Beliefs.] Moscow: Izd-vo Akademii nauk SSSR. Available at http://biblio.imli.ru/images/abook/folklor/CHicherov_V.I._Zimnij_period_ russkogo_narodnogo_zemledelcheskogo_kalendarya_XVI_-_XIX_vekov._1957. pdf, last accessed on 27 June 2019.

Dmitrieva, Svetlana 1988. Fol'klor i narodnoie iskusstvo Russkikh Evropeiskogo Severa. [Folklore and Folk Art of Russians of the European North.] Moscow: Nauka. Available at https://www.booksite.ru/fulltext/dmitrieva/text.pdf, last accessed on 23 July 2019.

Drannikova, Natalia 2000. Materialy k Pinezhskomu etnodialektnomu slovariu. [Materials for Pinega Ethic and Dialect Dictionary.] Zhivaia starina, No. 1, pp. 45-47. Available at https://inslav.ru/sites/default/files/zhs-2000-1.pdf, last accessed on 27 June 2019.

Efremova, Tatiana 2000. Novyi slovar' russkogo iazyka. Tolkovo-slovoobrazovatel'nyi. [New Dictionary of the Russian Language: Explanatory and Word-Forming.] Moscow: Russkii iazyk. Available at http://www.efremova.info, last accessed on 27 June 2019. Korepova, Klara 2009. Russkie kalendarnye obriady i prazdniki Nizhegorodskogo Povolzh'ia. [Russian Calendar Rituals and Holidays of the Nizhny Novgorod Volga Region.] St. Petersburg: Tropa Troianova.

Krasheninnikova, Yulia 2011. Russkie svadebnye prigovory v svete narodnoi terminologii. [Russian Wedding Chants in the Light of Folk Terminology.] Traditsionnaia kul'tura, No. 3, pp. 70-80. Available at http://www.trad-culture.ru/article/russkiesvadebnye-prigovory-v-svete-narodnoy-terminologii, last accessed on 27 June 2019. 
Krasheninnikova, Yulia 2019. Historical Folklore Prose of the Russian Metallurgical Traditions of the Komi Republic. Folklore: Electronic Journal of Folklore, Vol. 76, pp. 135-154. https://doi.org/10.7592/FEJF2019.76.krasheninnikova.

Neklyudov 2011 = Nekliudov, Sergei. Gorodskaia pesnia: pamiat' detstva. [City Song: Memory of Childhood.] Zhivaia starina, No. 1, pp. 19-22. Available at https:// inslav.ru/sites/default/files/zhs-2011-1.pdf, last accessed on 27 June 2019.

Ozhegov, Sergei 1987 [1949]. Tolkovyi slovar' russkogo iazyka. [Explanatory Dictionary of the Russian Language.] Izdanie 18, stereotipnoe. Moscow: Russkii iazyk.

Rozov, Aleksandr 1999. Russkoe rozhdestvenskoe khristoslavlenie (materialy i issledovanie). [Russian Christmas Glorification of Christ (Materials and Study).] In: A. Rozov (ed.) Russkii fol'klor: materialy i issledovaniia. [Russian Folklore: Materials and Studies]. Vol. 30. St. Petersburg: Nauka, pp. 20-53. Available at http://lib2.pushkinskijdom.ru/Media/Default/PDF/RusFolk/RusFolklore\%20 vol.30\%201999.pdf, last accessed on 27 June 2019.

Safronov, Evgeny 2011. Osobennosti ul'ianovskikh Sviatok. [Peculiarities of Ulyanovsk Christmas.] Ulpressa, 6 January. Available at https://ulpressa.ru/2011/01/06/ article143757/, last accessed on 21 June 2019.

SRIa 1982 = Slovar' russkogo iazyka XI-XVII vv. [Dictionary of the Russian Language of the 11th-17th Centuries.] Vyp. 9. Chief ed. F. Filin. Moscow: Nauka.

SRNG 1997 = Slovar' russkikh narodnykh govorov. [Dictionary of Russian Popular Dialects.] Chief ed. F. Sorokoletov. Vyp. 31. St. Petersburg: Nauka. Available at https://iling.spb.ru/dictionaries/srng/31.pdf, last accessed on June 27, 2019.

Ushakov, Dmitriy (ed.) 1938. Tolkovyi slovar' russkogo iazyka. [Explanatory Dictionary of the Russian Language.] Vol. 2. Moscow: Gosudarstvennoe izdatel'stvo inostrannykh i natsional'nykh slovarei.

Ushakov, Dmitriy (ed.) 1939. Tolkovyi slovar' russkogo iazyka. [Explanatory Dictionary of the Russian Language.] Vol. 3. Moscow: Gosudarstvennoe izdatel'stvo inostrannykh i natsional'nykh slovarei.

Vinogradov, Georgiy 1998. "Strana detei": Izbrannye trudy po etnografii detstva. [Country of Children: Selected Works on Childhood Ethnography.] St. Petersburg: Istoricheskoe nasledie.

Vinogradova, Liudmila 1982. Zimniaia kalendarnaia poeziia zapadnykh $i$ vostochnykh slavian. Genezis i tipologiia koliadovaniia. [Winter Calendar Poetry of Western and Eastern Slavs: Genesis and Typology of Christmas Visitations.] Moscow: Nauka. Available at https://inslav.ru/publication/vinogradova-l-n-zimnyayakalendarnaya-poeziya-zapadnyh-i-vostochnyh-slavyan-genezis-i, last accessed on 27 June 2019.

Vlasov, Andrey (ed.) 1995. Traditsionnyi fol'klor Vilegodskogo raiona Arkhangel'skoi oblasti (v zapisiakh 1986-1991 gg.): Issledovaniia $i$ materialy. [Traditional Folklore of Vilegodsk District (in the Records of 1986-1991). Research and Materials.] Syktyvkar: Syktyvkarskii gosudarstvennyi universitet. Available at https://territory.syktsu.ru/etnokulturnoe-nasledie/biblioteka/13.pdf, last accessed on 12 July 2019.

Voroshilin, Viacheslav 2009. Pesni novogodnikh i rozhdestvenskikh obkhodov v Voronezhskoi oblasti. [Songs of New Year and Christmas Visitations in Voronezh Oblast.] Zhivaia starina, No. 4, pp. 30-34. Available at https://inslav.ru/sites/ default/files/zhs-2009-4.pdf, last accessed on 27 June 2019. 